\title{
Family Caregivers of Terminally Ill Patients at Home: Contributions for a Supervision Model
}

\author{
Prestadores de Cuidados Familiares a Pessoas Terminais no Domicílio: Contributos para \\ um Modelo de Supervisão \\ Cuidadores Familiares de Pacientes Terminales en el Domicilio: Contribuciones a un \\ Modelo de Supervisión \\ Maria João Cardoso Teixeira*; Wilson Jorge Correia de Abreu**; Nilza Maria Vilhena Nunes da Costa***
}

\begin{abstract}
Background: Nowadays, family caregivers play a critical role in the support of terminally ill at home. However, there are relatively few supervision models to help nurses in make decisions.

Objectives: Contribute to a caregiver supervision model.

Methodology: In a prior study, the needs of 10 terminally ill and their caregivers were identified. In the present study, based on a focus group, 8 expert nurses analysed the needs and validated both the functions and the focus of supervision.

Results: Data on terminally ill patients confirm the normative function of supervision through the diagnostic criteria for self-care deficit and risks. The formative function of supervision is evident when family caregivers have no knowledge/skills to provide care or are not aware of a problem. Finally, the restorative function concerns the assessment of the caregivers' physical, emotional and relational capacity, as well as their time and resources available to provide care.

Conclusion: The contributions of our study emphasises a 3 function model that covers the needs of terminally ill patients and their family caregivers.
\end{abstract}

Keywords: caregivers; terminally ill; home; self-care; nursing supervision; decision making

\section{Resumo}

Enquadramento: Atualmente, os prestadores de cuidados familiares desempenham um papel crucial no suporte a pessoas em situação terminal no domicílio. Existem poucos modelos de supervisão que ajudem os enfermeiros na tomada de decisão.

Objetivos: Contribuir para um modelo de supervisão para cuidadores. Metodologia: Num estudo prévio, identificaram-se as necessidades de 10 pessoas terminais e respetivos prestadores de cuidados. Neste estudo, baseado em focus group, 8 enfermeiras peritas analisaram as necessidades e validaram as funções/ focos de supervisão.

Resultados: Os dados referentes à pessoa terminal evidenciaram a função normativa da supervisão através dos critérios de diagnóstico para o défice no autocuidado e riscos. A função formativa emerge quando o familiar prestador de cuidados não possuí conhecimentos/ habilidades para tomar conta ou consciência de determinado problema. Por último, a função restaurativa destaca-se na avaliação da capacidade física, emocional e relacional de quem cuida assim como na disponibilidade de tempo e dispositivos necessários.

Conclusão: Os contributos do estudo relacionam-se com as 3 funções supervisivas, englobando as necessidades da pessoa e familiares prestadores de cuidados.

Palavras-chave: cuidadores; doente terminal; domicilio; autocuidado; supervisão de enfermagem; tomada de decisão

\footnotetext{
* RN, Sobell House, Oxford University Hospital, Oxford OX3 7LE, England [mariajoao.teixeira@ouh. nhs.uk]. Contribution to the article: study design, literature search, data collection and treatment, data analysis and discussion, article writing and revision. Address for correspondence: Sobell House Churchill Hospital, Headington, Oxford OX3 7LE, England.

** Ph.D., Full Professor, Nursing School of Porto, 4200-072, Porto, Portugal [wjabreu@esenf.pt]. Contribution to the article: data discussion, article revision and correction.

*** Ph.D., Full Professor, University of Aveiro, 3810-193, Aveiro, Portugal [nilzacosta@ua.pt]. Contribution to the article: data discussion, article revision and correction.
}

\section{Resumen}

Marco contextual: En la actualidad, los cuidadores familiares desempeñan un papel crucial en el apoyo a las pacientes terminales en domicilio. Hay pocos modelos de supervisión que ayuden a los enfermeros a tomar decisiones.

Objetivos: Contribuir a un modelo de supervisión del cuidador familiar

Metodología: En un estudio anterior, hemos identificado 10 pacientes terminales y sus respectivos cuidadores familiares. En este estudio, basado en focus group, 8 enfermeras expertas analizaron las necesidades y validaron las funciones/enfoque de supervisión.

Resultados: Los datos del paciente terminal demuestran la función normativa de supervisión a través de los criterios de diagnóstico para el déficit en el autocuidado y los riesgos. La función formativa emerge cuando el cuidador familiar no posee conocimientos o habilidades para cuidar o incluso tomar consciencia de un determinado problema. Por último, la función restaurativa comprende la evaluación de la capacidad física, emocional y relacional de los cuidadores, así como la disponibilidad de tiempo y dispositivos necesarios.

Conclusión: Las contribuciones de nuestro estudio destacan las 3 funciones de modelo y abragem las encessidades del patient terminal y los respectivos cuidadores familiares.

Palabras clave: cuidadores; paciente terminal; hogar; autocuidado; supervisión de enfermería; toma de decisiones

Received for publication: 07.09 .15

Accepted for publication: 01.02 .16 


\section{Introduction}

The number of people with incurable chronic diseases who wish to die at home is increasing, especially if they live with and are cared for their family (Payne, 2010). In 2005, in the European Union (21 countries), there was an estimated 19 million informal caregivers over the age of 25 and, of these, 9 million were providing care for at least 35 hours a week. By 2030, it is estimated that there will be 21.5 million informal caregivers over the age of 25 providing care for at least 20 hours a week, and 10.9 million informal caregivers providing care for at least 35 hours per week. The importance of the family caregiver, particularly at home, is increasingly evident within the scope of care provision (Glendinning, Arksey, \& Tjadens, 2009).

Family caregivers take care of activities, from house safety, going shopping, and cooking to providing care given the self-care deficit and shopping complications. When the health status of terminally will deteriorates, the level of care needs increase.

The main objective of this study is to contribute to the creation of a supervision model based on the needs of family caregivers of terminally ill patients, as well as on the resources needed to provide care at home. Research shows that these caregivers report various needs, but are also unaware of other needs (Machado, 2014). These needs relate to the acquisition of both knowledge and skills that empower them to provide competent care with the least possible negative consequences (Silva, Teixeira, Teixeira, \& Freitas, 2013).

\section{Background}

Being a family caregiver is socially interpreted as an intrinsic function to the human condition. This role is usually associated with wives, daughters or daughtersin-law who are responsible for performing the tasks that their relatives with disabilities are unable to perform (Funk et al., 2010). Caring for a terminally ill patient at home brings about changes in family dynamics, which are often ignored by health care professionals and have negative consequences both for patients and caregivers (Dumont, Jacobs, Turcotte, Anderson, \& Harel, 2010).

To cope a new situation, an early preparation can facilitate the transition, whereas, on the contrary, the lack of preparation is an inhibiting factor (Pazes, Nunes, \& Barbosa, 2014) and may influence the caregiving role. Studies show that better prepared family caregivers have a lower level of stress and are more more satisfied with caregivers role's performs (Hudson, Remedios \& Thomas, 2010).

However, several studies show that health care professionals, especially nurses, still pay little attention to these caregivers based on their real needs and the specific health status of the terminally ill person (Teixeira, 2015).

In the literature review conducted, we identified multiple studies focusing on terminally ill patients or on their family caregivers. In relation to terminally ill people, the studies describe their health condition and the respective intervention programs which are largely associated with symptom management and the type of care that relatives should provide. Many studies already focus on the family caregivers and on their needs, intervention programs, and assessment of consequences. However, the diversity of data collection tools, evaluations and contexts hamper the development of a logic model for clinical decisionmaking (Teixeira, 2015).

In the studies analysed, we identified a lack of instruments that synthesized the clinical evaluation of the self-care deficit and risks of terminally ill patients or that described the data related to the caregiving role that should be assessed in family caregivers.

One of the nurses' tasks is to help family caregivers performing their role without ever forgetting the needs of the terminally ill patients. The assessment of the needs of this dyad in view of the evolution of the health condition of the terminally ill patient and the needs of the caregiver is a support strategy in simultaneous transitions (Abreu, 2008).

According to the Proctor's model (1986), three supervisory functions can occur (separately or combined): normative, formative, and restorative. Given the relevance of the supervisory role of nurses in the assessment of the needs of terminally ill patients and their family caregivers, and the lack of knowledge about the evidence of supervision model to these clients, we aimed contribute to a model able of operational the different supervisory functions, focusing on the clinical assessment of the self-care deficit and risks of the terminally ill patient and, simultaneously, on the assessment of the family caregiver's capacity to perform this role. 


\section{Research questions}

This study describes the second part of a major qualitative research. Four research questions were formulated to the first part: In the first moment, the following questions were formulated: Which diagnostic data contribute to the self-care deficit and risks of the terminally ill patient? And what type of care is provided by family caregivers and what needs do they perceive? This second part of the study was guided by the following operational questions: which dimensions should be included in a supervision model focused on the family caregivers? What are the key focus to consider in each dimension?

\section{Methodology}

Our main purpose was to describe the second part of the study focused on the supervisory process - selected dimensions and focus. However, we will describe the methods utilized in the first part, to provide a better and easy understanding of the research process. As told before, we conducted previously a qualitative study with an ethnographic inspiration in home settings, Ethnography contributed to describe and explain both the consistencies and the variations in social behavior (Graneheim, Johansson, \& Lindgren, 2013). It allowed understanding the personalities, the society, the individuals and the contexts from the perspective of others and not as a result of a clinical trial. "Ethnography offers one of the best ways to understand these complex features of modern life. It can show the range of cultural differences and how people with diverse perspectives interact." (Spradley, 1980, p.16).

All the above mentioned arguments strengthen our methodological option, especially when Spradley (1980, p.18) defines culture "as the acquired knowledge people use to interpret experience and generate behavior", which is in line with the objectives set out for this study.

\section{First Moment - Prior Study}

Through a descriptive and qualitative study ethnography, it was possible to identify the care needs of terminally ill people concerning self-care deficit and risks, as well as the needs of family caregivers. The participants were intentionally selected, with the help of privileged informants (nurses and family doctors). The qualitative approach favors the criteria sampling, i.e. certain inclusion criteria can be used to fully apprehend the caretaking focus (International Council of Nurses [ICN], 2013).

The following criteria were used to select the participants: being a relative in charge of the unpaid organization or provision of care; being over 18 years of age; and caring, at any time of the day, for a person with advanced and progressive disease. Regarding the patients, we defined the following inclusion criteria: having an advanced and progressive disease, without healing potential; being over 18 years of age; being dependent on self-care and homebound.

Since this is a study of ethnographic inspiration, participant observation remained the

selected technique, that was used to identify the individuals' activities, the physical characteristics of the social situation and the aspects that are part of the scenario under study. Initially, a descriptive observation was used to obtain an overview of the social situation. After registration and analysis of baseline data, we conducted focused observations. Finally, after consecutive observations and analyzes, we finished with selective observations (Spradley, 1980), finding further evidence on specific domains to develop a taxonomy. However, sometimes it was necessary to add more descriptive information to facilitate the data classification.

Data collection took place between December 2012 and June 2013 and was complemented with semistructured interviews and field notes (within the context of observation) so as to facilitate data analysis. Eleven interviews and 33 observation sessions were performed and the respective field notes were taken. Bardin's (2009) technique was used to perform content analysis and data categorization. The WebQDA software (Souza, Costa, \& Moreira, 2011) was used to consolidate a hierarchical encoding structure, allowing for a quick and rigorous access to information. This structure was based on the data sets encoded in the International Classification for Nursing Practice - Version 2013 (ICN, 2013).

All interviews, observations and field notes were repeatedly read to obtain an overall understanding of the experience of each participant. After this phase, the analytical domains were obtained through the following steps (Spradley, 1980): a) selecting a simple semantic relationship; (b) preparing a domain 
worksheet that had to be constantly updated; c) selecting a sample of the obtained data; d) searching for possible cover terms and included terms that fit the semantic relationship; e) repeating the search with other semantic relationships; f) listing the identified domains.

In view of the obtained domains, and based on Spradley's model (1980), we considered: a) personal interest; b) informants' suggestions; c) theoretical interest; (d) ethnographic strategy; e) organization of domains. f) listing the domains that we selected to perform the focused observations; g) writing the questions that would help to perform the observation; h) selecting the venues that would provide the best opportunity for observation; and i) selecting the activities that would enable the observation.

The categories were identified as the data were being explored and reduced from the research on the topic as well as from the subjectivity that emerged from the interviews with the family caregivers.

In the process of categorization, the following assumptions were considered: (a) the exhaustiveness of the categories, where the system of categories would encompass all possible differentiated data units; (b) mutual exclusion, where each unit could only exist in a category: c) pertinence, i.e. the categories would be related to the objectives and the content of the information (units of record); and, finally, d) objectivity, by assigning a single classification principle, which implies that the categories are drawn up based on a single classification criterion (Bardin, 2009).

A final taxonomy was defined, i.e. a set of categories based on a single semantic relationship (Mozzato \& Grzybovski, 2011). Data were categorized according to the diagnostic criteria for the terminally ill person, which has caused dependence on self-care and risk of complications. The data related to family caregivers were divided into physical capacity, emotional capacity, relational capacity and time availability. These data also included the expressed or unmeet needs of potential to improve knowledge and/or skills and increase the awareness of a given need. The unperceived needs result from cross-linking the data on the terminally ill patient and the care not provided by the caregiver due to a lack of knowledge or awareness of the problem. The third level of categorization encompasses the formal and informal support available to the family caregiver, as well as the equipment available for caretaking. The contributions were obtained in combination with the defined categories and the literature review supporting the decision choices. It aims at the clinical usefulness for decision-making through analysis of the presence or not of Yes or No data.

\section{Second Moment - The Actual Study}

Content analysis guarantees the validity of the contributions, i.e. it determines if they objectively represent reality or not. The experts selected to collaborate in this phase were nurses with the highest level of professional and disciplinary knowledge on the theme and the population under study. The Delphi's technique (Hasson,

Keeney \& McKenna, 2000) was used to reach a consensus without the need for

an in-person group. The group of participants was composed of eight female nurses with a mean age of 36 years. Two of the experts worked at a family health unit, two in continuous care teams, three in hospital palliative care units, and one in an intrahospital palliative care team.

In relation to the experience in providing care with family caregivers, the mean years of experience were 12.1 years, being the minimum experience of 2 years and the maximum experience of 21 years. The mean years of experience in caring for terminally ill people were 9.6 years, being the minimum experience of 2 years and the maximum experience of 21 years. It was important to emphasise that all of the experts are familiar to palliative care, international classification of nursing practice and clinical supervision.

\section{Results}

As for the level of education, three experts had a 4-year undergraduate degree (mean of 9.3 years); five had a three-year undergraduate degree (mean of 19.4 years) and the respective training complement (mean of 11.6 years); five held a Master's degree, three of them in Palliative Care (mean of 3 years), one in Oncology (for 6 years) and another in Bioethics (for 8 years). In addition, three of the experts had postgraduate degrees in palliative care.

With regard to the level of specialization, six experts undertook specialized training in nursing areas: three in community nursing with a mean age of 4 years 
in the profession; one in community nursing for 8 years; one in medical-surgical nursing for 6 years, and, finally, one expert in rehabilitation nursing for 3 years. In the definition of the type of consensus, it was taken in account the analysis of the scores obtained in each question using a 5-point Likert scale. Thus, the inclusion consensus was reached whenever the following conditions were met for each item: a degree of mean and median concordance equal to or greater than 4, and lack of participants' comments, such as ambiguity in understanding data (Goossen, 2000). The exclusion consensus was found when the degree of mean and median concordance was less than 3 and there were comments on data ambiguity.

The study was approved by the Ethics Committee of the North Regional Health Authority (ARS Norte), and the informed consent was obtained from the participants belonging to a rural village in the district of Porto.

The work developed by the experts was focused on the supervisory relationship with the caregivers. However, we will remark here the main characteristics of the caregivers. The sample included 10 family caregivers and 10 terminally ill patients, characterized as follows: Thus, the sample age of the family caregivers was 59 years, nine were women and eight were unemployed; the mean age of the patients was 84 years, eight were women, dementia was the main medical diagnosis, one patient had an oncological disease and another had a degenerative bone disease). All participants required permanent care (Table 1).

\section{Table 1}

Characterization of participants

\begin{tabular}{|c|c|c|}
\hline & $\begin{array}{l}\text { Terminally Ill Patient (TIP) } \\
\qquad n=10\end{array}$ & $\begin{array}{l}\text { Family Caregiver (FC) } \\
\qquad n=10\end{array}$ \\
\hline Age (mean) & $\begin{array}{c}84 \text { years } \\
(72-93 \text { years })\end{array}$ & $\begin{array}{c}59 \text { years } \\
\text { (47-78 years) }\end{array}$ \\
\hline \multicolumn{3}{|l|}{ Gender } \\
\hline Female & 8 & 9 \\
\hline Male & 2 & 1 \\
\hline \multicolumn{3}{|l|}{ Education } \\
\hline Secondary & 1 & 5 \\
\hline Primary & 7 & 4 \\
\hline Illiterate & 2 & 1 \\
\hline \multicolumn{3}{|l|}{ Marital status } \\
\hline Single & 1 & 0 \\
\hline Married & 3 & 9 \\
\hline Widowed & 6 & 0 \\
\hline Divorced & 0 & 1 \\
\hline \multicolumn{3}{|l|}{ Occupation } \\
\hline Unemployed & 0 & 6 \\
\hline Employed & 0 & 0 \\
\hline Retired & 10 & 4 \\
\hline \multicolumn{3}{|l|}{ Relationship between the TIP and FC } \\
\hline Mother & 5 & \\
\hline Brother & 1 & \\
\hline Wife & 1 & \\
\hline Father/Mother-in-law & 2 & \\
\hline Aunt & 1 & \\
\hline $\begin{array}{l}\text { Years of dependence/Years of caregiving } \\
\text { (mean) }\end{array}$ & $\begin{array}{l}8 \text { years } \\
\text { (1-20 years) }\end{array}$ & $\begin{array}{l}8 \text { years } \\
\text { (1-20 years) }\end{array}$ \\
\hline \multicolumn{3}{|l|}{ Main disease } \\
\hline Dementia/Alzheimer & 8 & 0 \\
\hline Oncological disease & 1 & 0 \\
\hline \multirow[t]{2}{*}{ Degenerative bone disease } & 1 & 6 \\
\hline & \begin{tabular}{l|l} 
EIRA et al. & $\begin{array}{l}\text { Revista de Enferm } \\
\text { Journal of Nursing }\end{array}$
\end{tabular} & ila \\
\hline
\end{tabular}




\section{Discussion}

The contributions for clinical decision-making were defined specifically for each one of the risks and self-care deficit of terminally ill people. These data highlight the normative function that the nurse can perform, i.e. the professional responsibility in view of the observed reality. Data provide information that should be immediately considered so as to maintain the excellence of care. The results that will be describe are general results since the specific description for each diagnosis would be exhaustive.

In relation to the terminally ill person, the diagnosis criteria used for defining an impaired physical capacity are: impaired airway clearance, urinary incontinence, bowel incontinence, malign wound, dysphasia, pain, impaired consciousness, pressure ulcer, joint contrature, impaired balance, hypoactivity, and agitation. For impaired cognitive capacity, we consider the criteria related to impaired memory and confusion. These data may lead to self-care deficit. Self-care was subdivided into three categories: primary self-care, secondary self-care and tertiary self-care. Primary selfcare is the most basic care (moving, lifting, standing, transfer and sitting) and, if impaired, all other types of self-care are affected. The presence of deficit in these types of self-care results in deficits in secondary self-care (moving, lifting, standing, transfer and sitting) and in tertiary self-care, i.e. care which can be assisted or performed in full by third parties (selfbathing, self-toileting, self-dressing, self-grooming, self-feeding self-diverting and complex treatment regime - exercise regimen, complex medication regimen and dietary regimen).

An impaired physical and cognitive capacity and deficits in primary and secondary self-care mean that the terminally ill patient is at risk. These risks may be related to bodily processes: aspiration, dehydration, constipation, maceration, pressure ulcer, joint contrature. Elopement is related to the cognitive processes. The risk of fall and deficit in promoting self-care is related to self-care.
If the terminally ill patient requires a family caregiver, the nurse must assess the caregiver's physical, emotional and relational capacity and time availability to help in the self-care deficits or preventing complications. If the assessment is negative (presence of deficits), the family caregiver should be advised/referred to a formal or informal support. The normative has to be considered once again in professional exercise.

However, when the family caregiver expresses the need for knowledge and skills, the formative function of the nurse emerges. In this study, this formative function emerges when there is a need to deepen the caregiver's knowledge, for example, about preventing complications (aspiration, dehydration, pressure ulcer, contamination, deficit in promoting self-care), managing behavioral changes, the pathological and dying processes, managing a complex medication regimen, integrated continuous care teams, short/ medium-term units, palliative care units, and devices. In some cases, the caregiver's potential is focused on the acquisition of skills toward the empowerment for caretaking, which, in this study, relates to aspirating secretions, preventing complications (foot drop, pressure ulcer, aspiration, joint contrature), transferring and helping in toileting. Some family caregivers also required awareness on the risk of aspiration and maceration, family support and nursing services.

Caregivers are often faced with the breakdown of their own emotional sphere, either by exhaustion or concern over the lack of knowledge. Their adaptive capacity is altered, which requires support from the health professionals. In these cases, the nurse has a restorative or support function, i.e. the nurse is concerned with the caregiver's emotions, feelings and emotional intelligence. However, these functions often occur simultaneously, which indicates that nurses should be aware of all these needs in an comprehensive way.

Throughout this period of caregiving, the normative function is always present. However, the nurses 
should also assess the need for support that usually emerges in combination with the remaining needs. The family caregiver can also receive advice on devices/equipment designed to assist in caretaking, such as positional pillows, frame, bedpan, vaccum secretions, suspended bath seat, hair wash basin inflatable, bank/ plastic chair, bed or grabs rails, wheel chair, armchair, articulated armchair, commode, no fall shoes, automatic bed with rails, pill box, crutches, repose boots, urinary catheter, pressure relief mattress, sling back chair vest, plastic cup with holder, plastic cup with base, handrail, call device, pill cutter, transfer lift, medication delivery sheet, abdominal immobilizer, slide sheet, table adapted to wheelchair, leaflets, slide protection to plate, shower, ramps, plate guards, diapers/ inco sheets, board transfer, adapted clothes, urine bags, feeding syringes, nasogastric tube, transfer board, tray and anti-fall carpet. These resources may help caring for the person with one or more deficits and/or risks.

However, family caregivers who are unable to assist the person with self-care deficits or prevent complications need support: professional support (nurse, family doctor or integrated continuous care team), social support (operational assistants, day-care center/nursing homes, devices/equipment), family support (daughter, daughter-in-law, spouse, among others) or support from the continuous care network (palliative care units/short-term and long-term unit). The combination of different data of the terminally ill and family caregiver allow to build decisional flowcharts where the supervision's functions are present (Figura 1).

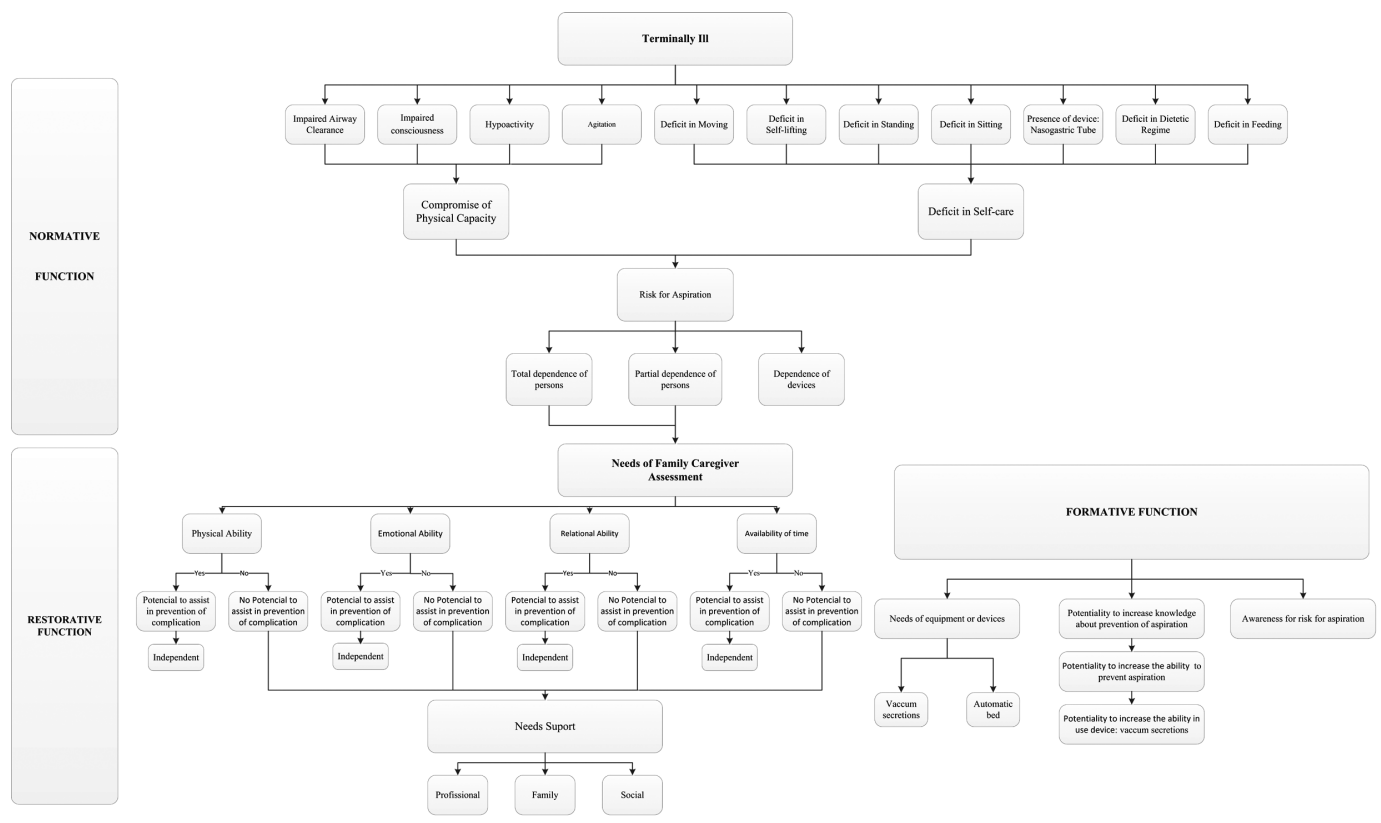

Figura 1.Example of decisional Flowchart for terminally ill with risk from aspiration.

This study allowed demonstrating the supervisory responsabilities of nurses and that this function may vary according to the needs of the terminally ill patient/family caregiver dyad. The caregiver may need to acquire skills in order to provide safe care (normative function), to explore and integrate new knowledge (formative function) or need to acquire skills of emotional management and psychological balance (restorative function). The main proposal of this study was to contribute toward a dynamic supervision model that would allow nurses to assess at any time the potential selfcare deficits and risks of terminally ill patients and, after assessing them, to evaluate the skills (physical, emotional and relational) and time availability of family caregivers, as well as the support and devices/ equipment that can enhance the caregiving role.

However, the study has some limitations. One of the limitations is the use of an intentional sample, selected within a specific period of time 
within a rural environment. In addition, the construction of categories only reflects the perception of a specific reality, despite having been assessed by experts. Further studies should be conducted with identical methodology in different (cultural and socioclinical) contexts.

\section{Conclusion}

The geometrically combined supervisory functions that were highlighted are based on data obtained in real care settings and in the literature review. Through the opinion of experts in the field of palliative care, we consolidated the we explored contributions for assisting terminally ill patients and respective family caregivers, assuming the data implementation in the care context.

By using a common terminology, we expect that findings from this study can be applied in the daily practice and subjected to continuous improvement in order to provide quality and safety care. We also aim at contributing to increasing the knowledge in nursing, as well as improving the medical records management software using the contents from the Nursing field.

Aware of the limitations of this study, we suggest that further research should be conducted on these contributions, namely on their application on a large scale, involving other nursing focus and the different relationships between them, always using real-life care situations validated data. We also suggest that instruments should be systematically applied to objectively assess the caregivers' physical, emotional and relational capacity, eliminating, as much as possible, any potential subjectivity in the assessment resulting from each nurse's individual clinical decision. Finally, we strongly suggest a debate about the meaning of Clinical Supervision. Research shows often a confusion between the concept of clinical supervision and students supervision. The supervision of the students, the peers supervision and the caregivers supervision have to be understood as different types of clinical supervision.

\section{Funding Source:}

This study was partially funded by the Isabel Levy Research Fellowship of the Portuguese Association of Palliative Care.

\section{References}

Abreu, W. J. (2008). Transições e contextos multiculturais: Contributos para a anamnese e recurso aos cuidadores informais. Coimbra, Portugal: Formasau.

Bardin, L. (2009). Análise de Conteúdo (3a ed.). Lisboa, Portugal: Edições 70 .

Dumont, S., Jacobs, P., Turcotte, V., Anderson, D., \& Harel, F. (2010). The trajectory of palliative care costs over the last 5 months of life: A Canadian longitudinal study. Palliative Medicine, 24(6), 630-640. doi: 10.1177/0269216310368453

Funk, L., Stajduhar, K. I., Toye, C., Aoun, S., Grande, G. E., \& Todd, C. J. (2010). Part 2: Home-based family caregiving at the end of life: A comprehensive review of published qualitative research (1998-2008). Palliative Medicine, 24(6), 594607. doi: $10.1177 / 0269216310371411$

Glendinning, C., Arksey, H., \& Tjadens, F. (2009). Care provision within families and its socio-economic impact on care providers: Report for the European Commission. Retrieved from http://europa.eu/epic/docs/eu-2342-care-provision.pdf

Goossen, W. T. (2000). Towards strategic use of nursing information in the Netherlands (Doctoral thesis). University of Groningen, Holland.

Graneheim, U., Johansson, A., \& Lindgren, B. (2013). Family caregivers' experiences of relinquishing the care of a person with dementia to a nursing home: Insights from a meta ethnographic study. Scandinavian Journal of Caring Sciences, 28(2), 215-224. doi: 10.1111/scs.12046

Hasson, F., Keeney, S., \& McKenna, H. (2000). Research guidelines for the Delphi survey technique. Journal of Advanced Nursing, 32(4), 1008-1015. doi: 10.1046/j.1365-2648.2000. t01-1-01567.x

Hudson, P. L., Remedios, C., \& Thomas, K. (2010). A systematic review of psychosocial interventions for family carers of palliative care patients. BMC Palliative Care, 9(1), 17. doi: 10.1186/1472-684X-9-17

International Council of Nurses. (2013). International classification for nursing practice. Genebra, Switerland: Author.

Machado, P. (2014). Papel do prestador de cuidados: Contributo para promover competências na assistência do cliente idoso com compromisso do autocuidado (Tese de doutoramento). Universidade Católica, Instituto de Ciências da Saúde, Porto, Portugal.

Mozzato, A., \& Grzybovski, D. (2011). Análise de conteúdo como técnica de análise de dados qualitativos no campo da administração: Potencial e desafios. Revista de Administração Contemporânea, 15(4), 731-747. Retrieved from http://www.redalyc.org/articulo.oa?id=84018975010

Payne, S. (2010). White paper on improving support for family carers in palliative care: Part 1. European Journal of Palliative Care, 17(5), 238-245. Retrieved from http://www. 
irishpsychiatry.ie/Libraries/External_Events_Documents/ EAPC_White_Paper_on_Family_Carers_Copy_1.sflb.ashx

Pazes, M. C., Nunes, L., \& Barbosa, A. (2014). Fatores que influenciam a vivência da fase terminal e de luto: Perspetiva do cuidador principal. Revista de Enfermagem Referência, 3, 95-104.

Proctor, B. (1986). Supervision: A co-operative exercise in accountability. In M. Marken, M. \& M. Payne (Eds.), Enabling and ensuring supervision in practice (pp. 21-23). Leicester, England: National Youth Bureau.

Silva, A., Teixeira, H. J., Teixeira, M. J., \& Freitas, S. (2013). The needs of informal caregivers of elderly people living at home: An integrative review. Scandinavian Journal of Caring Sciences, 27, 792-803. doi: 10.1111/scs.12019
Souza, F., Costa, A., \& Moreira, A. (2011) Análise de dados qualitativos suportada pelo software WebQDA. In Atas da VII conferência intenacional de TIC na educação: Chalanges 2011, Braga, 12-13 Maio 2011 (pp.49-56). Braga, Portugal: Universidade do Minho.

Spradley, J. P. (1980). Participant observation. Belmont, USA: Wadsworth Cengage Learning.

Teixeira, M. J. (2015). Impacto dos programas educacionais nos membros da família prestadores de cuidados de pessoas em fase terminal: Revisão integrativa. Pensar Enfermagem, 19(1), 2-18. Retrieved from http://pensarenfermagem.esel. pt/files/PE_19_1sem2015_2_18.pdf 
